Article

\title{
Leccinum molle (Bon) Bon and Leccinum vulpinum Watling: The First Study of Their Nutritional and Antioxidant Potential
}

\author{
Filipa S. Reis ${ }^{1,2,3,4}$, Lillian Barros ${ }^{1}$, Anabela Martins ${ }^{1}$, M. Helena Vasconcelos ${ }^{3,4,5}$, \\ Patricia Morales ${ }^{2}$ and Isabel C. F. R. Ferreira ${ }^{1, *}$ \\ 1 Mountain Research Center (CIMO), School of Agriculture, Polytechnic Institute of Bragança, Apartado 1172, \\ Bragança 5301-855, Portugal; freis@ipatimup.pt (F.S.R.); lillian@ipb.pt (L.B.); amartins@ipb.pt (A.M.) \\ 2 Dpto. Nutrición y Bromatología II, Facultad de Farmacia, Universidad Complutense de Madrid (UCM), \\ Pza Ramón y Cajal, s/n, Madrid E-28040, Spain; patricia.morales@farm.ucm.es \\ 3 i3S - Instituto de Investigação e Inovação em Saúde da Universidade do Porto, Rua Alfredo Allen, 208, \\ Porto 4200-135, Portugal; hvasconcelos@ipatimup.pt \\ 4 Cancer Drug Resistance Group, Institute of Molecular Pathology and Immunology of the University of \\ Porto, IPATIMUP, Rua Júlio Amaral de Carvalho, 45, Porto 4200-135, Portugal \\ 5 Laboratory of Microbiology, Department of Biological Sciences, Faculty of Pharmacy of the University of \\ Porto, Rua de Jorge Viterbo Ferreira 228, Porto 4050-313, Portugal \\ * Correspondence: iferreira@ipb.pt; Tel.: +351-273-303-219; Fax: +351-273-325-405
}

Academic Editor: Derek J. McPhee

Received: 21 December 2015; Accepted: 18 February 2016; Published: 20 February 2016

\begin{abstract}
This work presents the chemical profile of two edible species of mushrooms from the genus Leccinum: Leccinum molle (Bon) Bon and Leccinum vulpinum Watling, both harvested on the outskirts of Bragança (Northeastern Portugal). Both species were prepared and characterized regarding their content in nutrients (i.e., free sugars, fatty acids and vitamins), non-nutrients (i.e., phenolic and other organic acids) and antioxidant activity. To the best of our knowledge, no previous studies on the chemical characterization and bioactivity of these species have been undertaken. Accordingly, this study intends to increase the available information concerning edible mushroom species, as well as to highlight another important factor regarding the conservation of the mycological resources-their potential as sources of nutraceutical/pharmaceutical compounds. Overall, both species revealed similar nutrient profiles, with low fat levels, fructose, mannitol and trehalose as the foremost free sugars, and high percentages of mono- and polyunsaturated fatty acids. They also revealed the presence of bioactive compounds, namely phenolic (e.g., gallic acid, protocatechuic acid and $p$-hydroxybenzoic acid) and organic acids (e.g., citric and fumaric acids) and presented antioxidant properties.
\end{abstract}

Keywords: chemical profile; nutritional value; nutraceuticals; bioactive compounds; antioxidant potential

\section{Introduction}

Few studies exist on the Leccinum molle (Bon) Bon and Leccinum vulpinum Watling mushroom species. In the literature it is possible to find a description of the morphological features of L. molle [1], and some ecological [2-4] and enzymatic $[5,6]$ studies with L. vulpinum are available. As far as we know, these are the only studies performed to date, so even considering they are two species of edible mushrooms, they do not seem to be the most consumed by aficionados. However, their interest from the point of view of obtaining nutraceuticals cannot be excluded. Furthermore, apart from trying to 
valorize these natural resources by providing new information about their potential as a source of bioactive compounds and nutraceuticals, this study also aims to help in the construction of wild edible mushrooms databases.

Since Bragança (Portugal) is one of the regions of Europe with greater mycological biodiversity, it is important to undertake a careful identification and characterization of a large number of wild mushroom species. In addition, being also a region where mushroom picking is a tradition, the scientific community plays an important role in the formation of the general population. Furthermore, public awareness of the need for a careful and healthy diet has increased. In this sense, the consumption of vegetable proteins is increasingly advised and has been increasing over the years. This is due to many reasons including the prevalence of animal diseases, shortage of animal protein worldwide, the strong demand for healthy food, religion, as well as economic reasons [7]. In this regard, mushrooms have been recommended as an alternative protein source to meat, since they are rich in proteins, essential amino acids, vitamins and essential minerals [7,8]. Additionally, as further demonstrated in this work, many researchers have shown that mushrooms are also low in calories and fat [9-13]. Moreover, their primary (e.g., polysaccharides and glycoproteins) and secondary (e.g., phenolic compounds) bioactive compounds, make them a source of nutraceuticals and molecules having medicinal functions such as antioxidant, immunomodulating, and antitumour activity [14,15].

The present study is the first to quantify the nutritional and antioxidant potential of the aforementioned Leccinum species, paving the way for new and future studies related to the bioactivity of these species and wild mushrooms in general. Moreover, we intend to valorize these natural resources by advocating species conservation.

\section{Results}

\subsection{Nutrient Composition}

The nutrient composition of the studied species is presented in Table 1.

Table 1. Nutrients composition of wild samples of Leccinum molle (Bon) Bon and Leccinum vulpinum Watling (mean $\pm \mathrm{SD})$.

\begin{tabular}{llll}
\hline Nutrients & Leccinum molle (Bon) Bon & Leccinum vulpinum Watling & $p$-Value \\
\hline Ash $(\mathrm{g} / 100 \mathrm{~g} \mathrm{dw})$ & $5.70 \pm 0.55$ & $13.61 \pm 0.86$ & $<0.01$ \\
Proteins $(\mathrm{g} / 100 \mathrm{~g} \mathrm{dw})$ & $13.07 \pm 1.00$ & $10.48 \pm 0.50$ & 0.0156 \\
Fat $(\mathrm{g} / 100 \mathrm{~g} \mathrm{dw})$ & $2.80 \pm 0.16$ & $2.97 \pm 0.13$ & 0.1090 \\
Carbohydrates $(\mathrm{g} / 100 \mathrm{~g} \mathrm{dw})$ & $78.43 \pm 0.86$ & $72.94 \pm 0.51$ & 0.0007 \\
Energy $(\mathrm{kcal} / 100 \mathrm{~g} \mathrm{dw})$ & $391.18 \pm 0.99$ & $360.41 \pm 2.89$ & $<0.001$ \\
Fructose $(\mathrm{g} / 100 \mathrm{~g} \mathrm{dw})$ & $3.06 \pm 0.03$ & $4.52 \pm 0.14$ & $<0.0001$ \\
Mannitol $(\mathrm{g} / 100 \mathrm{~g} \mathrm{dw})$ & $11.32 \pm 0.30$ & $2.68 \pm 0.01$ & $<0.0001$ \\
Trehalose $(\mathrm{g} / 100 \mathrm{~g} \mathrm{dw})$ & $2.71 \pm 0.09$ & $8.31 \pm 0.01$ & $<0.0001$ \\
Total sugars $(\mathrm{g} / 100 \mathrm{~g} \mathrm{dw})$ & $17.09 \pm 0.24$ & $15.51 \pm 0.14$ & 0.0002 \\
C16:0 (relative percentage) & $11.23 \pm 0.21$ & $12.25 \pm 0.25$ & 0.0011 \\
C18:0 (relative percentage) & $1.79 \pm 0.01$ & $2.77 \pm 00.04$ & $<0.0001$ \\
C18:1n9 (relative percentage) & $38.61 \pm 0.33$ & $27.06 \pm 0.09$ & $<0.0001$ \\
C18:2n6 (relative percentage) & $43.49 \pm 0.10$ & $53.60 \pm 0.37$ & $<0.0001$ \\
SFA (relative percentage) & $16.94 \pm 0.41$ & $17.09 \pm 0.31$ & 0.4377 \\
MUFA (relative percentage) & $39.29 \pm 0.31$ & $28.59 \pm 0.04$ & $<0.0001$ \\
PUFA (relative percentage) & $43.77 \pm 0.10$ & $54.32 \pm 0.27$ & $<0.0001$ \\
$\alpha$-Tocopherol $(\mu \mathrm{g} / 100 \mathrm{~g} d w)$ & $12.48 \pm 0.70$ & $14.76 \pm 1.13$ & 0.0137 \\
$\beta$-Tocopherol $(\mu \mathrm{g} / 100 \mathrm{~g} \mathrm{dw})$ & $12.88 \pm 0.99$ & $216.18 \pm 0.90$ & $<0.0001$ \\
$\gamma$-Tocopherol $(\mu \mathrm{g} / 100 \mathrm{~g} \mathrm{dw})$ & $\mathrm{nd}$ & $296.67 \pm 0.19$ & 0.0032 \\
Total tocopherols $(\mu \mathrm{g} / 100 \mathrm{~g} \mathrm{dw})$ & $25.36 \pm 0.29$ & $527.61 \pm 2.22$ & 0.0008 \\
\hline
\end{tabular}

dw: dry weight; nd: not detected; main fatty acids: C16:0 (palmitic acid), C18:0 (stearic acid), C18:1n9 (oleic acid) and C18:2n6 (linoleic acid); 20 more fatty acids were identified in trace amounts; SFA: saturated fatty acids; MUFA: monounsaturated fatty acids; PUFA: polyunsaturated fatty acids. 
Regarding fat contents, there were no significant differences between both samples ( $p$-value $0.1090)$. Moreover, both species revealed a low fat content $(2.80-2.97 \mathrm{~g} / 100 \mathrm{~g} \mathrm{dw})$ compared to proteins (10.48-13.07 g/100 g dw) and particularly carbohydrates (72.94-78.43 g/100 g dw).

From a nutritional standpoint, it is also important to identify the soluble sugars present in the samples. The soluble sugars identified in the studied species were fructose (3.06-4.52 g/100 g dw), mannitol (2.68-11.32 g/100 g dw) and trehalose (2.71-8.31 g/100 g dw) (Table 1).

Considering the fatty acids composition, both species revealed a similar profile, with palmitic acid (C16:0), stearic (C18:0), oleic (C18:1n9) and linoleic acid (C18:2n6) being the main fatty acids present (Table 1). Although palmitic and stearic acids are saturated fatty acids (SFA), these are present in much lower quantities in both species, compared to oleic (a monounsaturated fatty acid-MUFA) and linoleic (a polyunsaturated fatty acid-PUFA) acids. In addition to the lower values, both species revealed similar SFA contents, without significant differences between them (16.94\% and $17.09 \%)$.

Apart from the abovementioned nutrients, we also assessed the presence of certain vitamins, namely some isoforms of vitamin $\mathrm{E}$ (especially known for its antioxidant activity). $\alpha$ - and $\beta$-tocopherol were present in both species, but only L. vulpinum revealed the presence of the $\gamma$-isoform (Table 1 ). In fact, $\gamma$-tocopherol was the prevailing isoform in this species, which contributed heavily to the much higher value of total tocopherols $(527.61 \mu \mathrm{g} / 100 \mathrm{~g} \mathrm{dw})$ compared with L. molle $(25.36 \mu \mathrm{g} / 100 \mathrm{~g} \mathrm{dw})$.

\subsection{Non-Nutrient Composition}

The study of some compounds other than nutrients, i.e., phenolic and other organic acids, was performed in both samples. The results are summarized in Table 2.

Table 2. Non-nutrient composition of wild samples of Leccinum molle (Bon) Bon and Leccinum vulpinum Watling (mean $\pm \mathrm{SD}$ ).

\begin{tabular}{llll}
\hline Compounds & Leccinum molle (Bon) Bon & Leccinum vulpinum Watling & $p$-Value \\
\hline Oxalic acid $(\mathrm{g} / 100 \mathrm{~g} \mathrm{dw})$ & $0.29 \pm 0.03$ & $0.11 \pm 0.01$ & 0.0002 \\
Quinic acid (g/100 g dw) & nd & $0.13 \pm 0.01$ & $<0.0001$ \\
Citric acid $(\mathrm{g} / 100 \mathrm{~g} \mathrm{dw})$ & $2.62 \pm 0.16$ & $\mathrm{nd}$ & $<0.0001$ \\
Fumaric acid $(\mathrm{g} / 100 \mathrm{~g} \mathrm{dw})$ & $1.04 \pm 0.02$ & $0.25 \pm 0.01$ & $<0.0001$ \\
Total organic acids $(\mathrm{g} / 100 \mathrm{~g} \mathrm{dw})$ & $3.95 \pm 0.19$ & $0.49 \pm 0.01$ & $<0.0001$ \\
Gallic acid $(\mathrm{mg} / 100 \mathrm{~g} \mathrm{dw})$ & $\mathrm{nd}$ & $0.08 \pm 0.01$ & $<0.0001$ \\
Protocatechuic acid $(\mathrm{mg} / 100 \mathrm{~g} \mathrm{dw})$ & $\mathrm{nd}$ & $0.35 \pm 0.05$ & $<0.0001$ \\
-Hydroxybenzoic acid $(\mathrm{mg} / 100 \mathrm{~g} \mathrm{dw})$ & $0.06 \pm 0.01$ & $0.09 \pm 0.01$ & 0.0002 \\
Total phenolic acids $(\mathrm{mg} / 100 \mathrm{~g} \mathrm{dw})$ & $0.06 \pm 0.01$ & $0.52 \pm 0.05$ & $<0.0001$ \\
Cinnamic acid $(\mathrm{mg} / 100 \mathrm{~g} \mathrm{dw})$ & $0.13 \pm 0.01$ & $0.17 \pm 0.01$ & $<0.0001$ \\
\hline
\end{tabular}

nd: not detected; dw: dry weight.

Analysing the results obtained, oxalic, quinic, citric and fumaric acids were the main organic acids identified. Oxalic and fumaric acid were found in both mushrooms $(0.11-1.04 \mathrm{~g} / 100 \mathrm{~g} \mathrm{dw})$. However, the profiles differ due to the presence of quinic acid only in L. vulpinum $(0.13 \mathrm{~g} / 100 \mathrm{~g} \mathrm{dw})$ and citric acid in L. molle $(2.62 \mathrm{~g} / 100 \mathrm{~g} \mathrm{dw})$.

Regarding phenolic acids, the profiles also differ substantially among species (Table 1; Figure 1). L. molle has only present in its chemical constitution $p$-hydroxybenzoic acid $(0.06 \mathrm{mg} / 100 \mathrm{~g} \mathrm{dw})$ and the related compound cinnamic acid $(0.13 \mathrm{mg} / 100 \mathrm{~g} \mathrm{dw})$. On the other hand, the L. vulpinum profile, besides $p$-hydroxybenzoic acid $(0.09 \mathrm{mg} / 100 \mathrm{~g} \mathrm{dw})$ and the related compound cinnamic acid $(0.17$ $\mathrm{mg} / 100 \mathrm{~g} \mathrm{dw})$, also includes gallic acid $(0.08 \mathrm{mg} / 100 \mathrm{~g} \mathrm{dw})$ and protocatechuic acid $(0.35 \mathrm{mg} / 100 \mathrm{~g}$ $\mathrm{dw})$. 
A

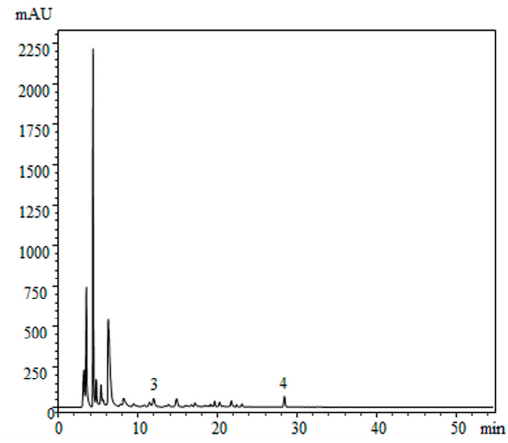

B

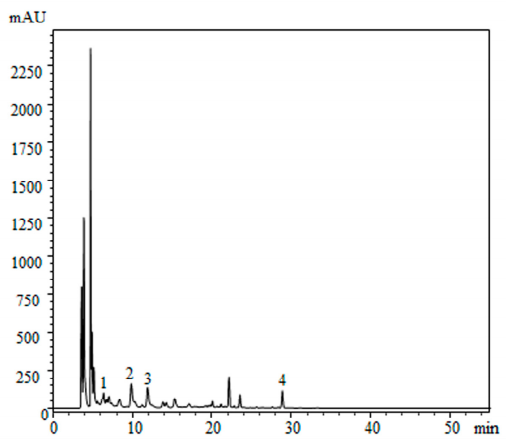

Figure 1. Phenolic acids profile of L. molle (A) and L. vulpinum (B) recorded at $280 \mathrm{~nm}$. 1: gallic acid; 2: protocatechuic acid; 3: $p$-hydroxybenzoic acid and 4: cinnamic acid.

\subsection{Antioxidant Potential}

The antioxidant properties of the samples were evaluated through different assays (Table 3). In order to estimate the reducing power of the samples, two different methodologies were performed: the Folin-Ciocalteu assay and the ferricyanide/Prussian blue assay. To evaluate the radical scavenging capacity, the 2,2-diphenyl-1-picrylhydrazyl (DPPH) radical was used, and to assess the lipid peroxidation inhibition, the $\beta$-carotene/linoleate and TBARS assays were performed.

Table 3. Antioxidant properties of the methanolic extracts of wild samples of Leccinum molle (Bon) Bon and Leccinum vulpinum Watling (mean $\pm \mathrm{SD}$ ).

\begin{tabular}{|c|c|c|c|c|}
\hline Activity & Assay & $\begin{array}{l}\text { Leccinum molle } \\
\text { (Bon) Bon }\end{array}$ & $\begin{array}{l}\text { Leccinum } \\
\text { vulpinum Watling }\end{array}$ & $p$-Value \\
\hline \multirow[b]{2}{*}{ Reducing Power } & $\begin{array}{l}\text { Folin-Ciocalteu assay } \\
\text { (mg GAE/g extract) }\end{array}$ & $17.76 \pm 0.26$ & $30.14 \pm 0.70$ & $<0.001$ \\
\hline & $\begin{array}{l}\text { Ferricyanide/Prussian } \\
\text { blue assay }\left(\mathrm{EC}_{50} ; \mathrm{mg} / \mathrm{mL}\right)\end{array}$ & $2.13 \pm 0.01$ & $0.54 \pm 0.01$ & $<0.001$ \\
\hline Radical scavenging activity & $\begin{array}{l}\text { DPPH radical-scavenging } \\
\text { activity assay } \\
\left(\mathrm{EC}_{50} ; \mathrm{mg} / \mathrm{mL}\right)\end{array}$ & $10.68 \pm 0.55$ & $1.19 \pm 0.02$ & $<0.001$ \\
\hline \multirow{2}{*}{ Lipid peroxidation inhibition } & $\begin{array}{l}\beta \text {-carotene/linoleate assay } \\
\left(\mathrm{EC}_{50} ; \mathrm{mg} / \mathrm{mL}\right)\end{array}$ & $2.23 \pm 0.05$ & $0.11 \pm 0.01$ & $<0.001$ \\
\hline & $\begin{array}{l}\text { TBARS assay } \\
\left(\mathrm{EC}_{50} ; \mathrm{mg} / \mathrm{mL}\right)\end{array}$ & $1.48 \pm 0.02$ & $0.03 \pm 0.00$ & $<0.001$ \\
\hline
\end{tabular}

Regarding the Folin-Ciocalteu assay, higher values mean higher reducing power; regarding the other assays, the results are presented as $\mathrm{EC}_{50}$ values, which mean that higher values correspond to lower reducing power or antioxidant potential. $\mathrm{EC}_{50}$ is the extract concentration corresponding to $50 \%$ of antioxidant activity or 0.5 of absorbance for the Ferricyanide/Prussian blue assay. Trolox EC 50 values: $41 \mu \mathrm{g} / \mathrm{mL}$ (reducing power), $42 \mu \mathrm{g} / \mathrm{mL}$ (DPPH scavenging activity), $18 \mu \mathrm{g} / \mathrm{mL}$ ( $\beta$-carotene bleaching inhibition) and $23 \mu \mathrm{g} / \mathrm{mL}$ (TBARS inhibition). GAE: gallic acid equivalents.

Generally, L. vulpinum revealed the highest antioxidant potential. This species displayed the highest reducing power, exhibiting the highest levels of reducing compounds evaluated by the Folin-Ciocalteu assay (30.14 mg GAE/g extract). Assessed through the ferricyanide/Prussian blue assay, the highest reducing power also belonged to L. vulpinum (lowest $\mathrm{EC}_{50}$ value $-0.54 \mathrm{mg} / \mathrm{mL}$ ).

This species also revealed the highest free radical scavenging activity $(1.19 \mathrm{mg} / \mathrm{mL})$ and lipid peroxidation inhibition, assessed through the $\beta$-carotene bleaching inhibition $(0.11 \mathrm{mg} / \mathrm{mL})$ and by the TBARS assay $(0.03 \mathrm{mg} / \mathrm{mL})$. 


\section{Discussion}

\subsection{Nutrient Composition}

As aforementioned, the nutritional value of the studied species was evaluated in order to recognize and value these species as healthy food. Table 1 shows that both species have low fat content, being richer in proteins and mostly in carbohydrates. Actually, the latter are described as the representative compounds of mushrooms, constituting nearby one-half of mushroom dry matter [11]. However, this group includes several compounds, such as sugars (monosaccharides, their derivatives and oligosaccharides) and the reserve and structural polysaccharides (glycans). So, given that it was intend to evaluate the nutritional value of the mushrooms, the soluble sugars presented by both species was assessed. The soluble sugars identified in the studied species were fructose, mannitol and trehalose (Table 1). Mannitol and trehalose are very common in mushrooms [11]. Regarding fructose, there are some studies relating the presence of this sugar to the trophism of the species. According to some authors [9], this sugar is mainly present in mycorrhizal species, which could justify its identification in these Leccinum species. However, this compound has already been identified in saprotrophic species [13]. Therefore, its presence seems then to be related to different factors other than the trophism.

Overall, both species revealed a typical nutritional profile described for mushrooms [10,11], so that they can be referred to as valuable nutritional healthy foods, since they are rich in protein and poor in calories and fat.

Moreover, although the fat levels are low, these include primarily unsaturated fatty acids. As presented in Table 1, although the saturated palmitic and stearic acids represented part of the main fatty acids found in the target species, oleic (MUFA) and linoleic (PUFA) acids were identified in much higher quantities. These findings are important both for the chemical characterization of the species as well as to promote their health benefits. It is well known that many beneficial effects have been attributed to the consumption of unsaturated fatty acids, particularly in relation to prevention of cardiovascular diseases [16,17].

As described in the previous section (Results), vitamin E was also found in the present study. Given the importance of this vitamin in preventing lipid peroxidation [18], its consumption through our daily diet is of the utmost importance. Regarding the obtained results, $\alpha$ - and $\beta$-isoforms were present in both species, while $\gamma$-tocopherol was only present in L. vulpinum (Table 1). This difference can be explained by the specificity of production of different metabolites characteristic of each species. As described in literature [19], some compounds may be produced by all varieties of a particular species or genus during their normal metabolism, while others may be specific of an organism.

According to the findings of this work, and presented in Table 1, both L. molle and L. vulpinum seem to be valuable healthy foods, being a source of mono- and oligosaccharides, mono- and polyunsaturated fatty acids and vitamin E.

\subsection{Non-Nutrient Composition}

The study of nutrient composition is very important to valorise the studied Leccinum species, since it provides information about the importance/benefits of their consumption. However, it is also important to study other molecules that may be biologically active. For this reason, an analysis of phenolic and other organic acids was undertaken in both samples (Table 2).

As mentioned above, both profiles were quite different between species. Therefore, some particular compounds may be mostly produced by a specific species, or their production may be related to the surrounding environment (e.g., possible subjection to stress conditions). In fact, the activation of secondary metabolism and increased production of phenolic compounds in response to various stress conditions is well documented [20].

As previous referred, although organic acids are considered non-nutrients, they are considered important molecules given their biological activities. For example, citric acid is known worldwide for 
its antioxidant activity and as a natural conservative. This makes L. molle as an alternative source of such interesting molecules. Quinic acid is also known for its antioxidant potential [21], which may be an indicator of such activity by L. vulpinum species. The other organic acids, oxalic and fumaric acids are also recognised bioactive compounds with pharmacological properties [22,23].

As presented in Table 2 and Figure 1, the chemical profile of L. vulpinum is richer in phenolic acids. The presence of these compounds is important because they are pointed out as biologically active molecules. They are often associated with hyperglycaemia and hypertension prevention [24], beneficial cardiovascular effects [25], or the antioxidant, antimicrobial and antitumor potential of the species [26,27]. Although there is a plethora of phenolic compounds occurring in nature, in our study (as in many studies about mushrooms) only the precursor cinnamic acid and two groups of phenolics were identified: some hydroxybenzoic acids (gallic, protocatechuic and $p$-hydroxybenzoic acids) and hydroxycinnamic acids ( $p$-coumaric acid). It should be noted that although flavonoids are occasionally reported as compounds present in mushrooms, these matrices do not have the biosynthetic pathway to produce them. Thus, it is believed that the flavonoids exceptionally present in some mushroom species, could be due to the symbiotic relationships established with plants [28]. We also should bear in mind that the chemical composition of mushrooms depends on the environment in which they grow. This is applied even more to secondary metabolites, such as phenolic compounds, which are usually produced in response to stress conditions [29]. Nonetheless, these compounds are present in small amounts in our sample, and the bioactivity present in this study could be correlated with these compounds, but also could be related to other compounds not identified in this study. Thus, the obtained results indicate that Leccinum species are a good source of nutrients and nutraceuticals, and their consumption is also a way to obtain phenolic and other organic acids.

\subsection{Antioxidant Potential}

The antioxidant properties of the samples were evaluated through different assays (Table 3). As mentioned, L. vulpinum revealed the highest antioxidant potential in all the performed assays. As expected, the bioactive properties of foods are directly related to the bioactive molecules present in their chemical constitution. Therefore, the antioxidant properties of the studied fruiting bodies must be related to some of the compounds studied in this work to present such antioxidant activity. L. molle showed higher levels of organic acids (3.95 g/100 $\mathrm{g} \mathrm{dw}$ ), which may be the basis of its antioxidant activity. On the other hand, L. vulpinum exhibited greater contents of phenolic acids and much higher values of tocopherols (527.61 $\mu \mathrm{g} / 100 \mathrm{~g} \mathrm{dw}$ ). Thus, vitamin E and phenolic acids may be largely responsible for the higher antioxidant activity of the species L. vulpinum. However, these results do not invalidate that other molecules (e.g., vitamin C, carotenoids, lycopene) may also be responsible for these properties.

\section{Experimental Section}

\subsection{Standards and Reagents}

Acetonitrile $99.9 \%$, $n$-hexane $95 \%$ and ethyl acetate $99.8 \%$ were of HPLC grade and obtained from Fisher Scientific (Lisbon, Portugal). The fatty acids methyl ester (FAME) reference standard mixture 37 (standard 47885-U) was purchased from Sigma (St. Louis, MO, USA) as were also other individual fatty acid isomers, standards of sugars, tocopherols, and organic acids, Trolox (6-hydroxy-2,5,7,8-tetramethylchroman-2-carboxylic acid) and phenolic standards. Racemic tocol (50 mg/mL), was purchased from Matreya (Pleasant Gap, PA, USA). 2,2-Diphenyl-1-picrylhydrazyl (DPPH) was obtained from Alfa Aesar (Ward Hill, MA, USA). All other reagents were acquired from specialized sellers. Water was treated in a Milli-Q water purification system (TGI Pure Water Systems, Greenville, SC, USA). 


\subsection{Mushroom Species and Sample Preparation}

Leccinum molle (Bon) Bon and Leccinum vulpinum Watling wild samples were collected in Bragança in the northeastern region of Portugal in the autumn of 2012. Authentications were undertaken at the Polytechnic Institute of Bragança and voucher specimens were deposited at the herbarium of the School of Agriculture of the Polytechnic Institute of Bragança, Portugal. After lyophilisation (FreeZone 4.5 model 7750031, Labconco, Kansas City, MO, USA), all the samples were milled and mixed to obtain a fine dried and homogeneous powder $(\approx 20 \mathrm{mesh})$, and then stored in a desiccator, until the time of the analysis.

\subsection{Nutrient Composition}

\subsubsection{Nutritional Value}

The nutritional value of the studied samples was calculated based on protein, fat, carbohydrate and ash contents obtained following standard procedures [30]. The crude protein content $(\mathrm{N} \times 4.38)$ of the samples was estimated as nitrogen content by the macro-Kjeldahl method; the crude fat by extracting a known weight of milled samples with petroleum ether, by means of a Soxhlet apparatus; and the ash content assessed after incineration at $600 \pm 15^{\circ} \mathrm{C}$. Total carbohydrates were calculated by difference. Energy was calculated according to Regulation (EC) No. 1169/2011 of the European Parliament and of the Council, of 25 October 2011, on the Provision of Food Information to Consumers [31], following the equation: Energy $(\mathrm{kcal} / 100 \mathrm{~g} \mathrm{dw})=4 \times(\mathrm{g}$ protein $+\mathrm{g}$ carbohydrate $)+$ $9 \times(\mathrm{g}$ fat $)$.

\subsubsection{Soluble Sugars}

Soluble sugars were assessed through chromatographic techniques-high performance liquid chromatograph (HPLC)—following a procedure already described [32]. The HPLC apparatus consisted of a pump (Smartline system 1000, Knauer, Berlin, Germany), a degasser system (Smartline manager 5000) and an auto-sampler (AS-2057 Jasco, Easton, MD, USA), coupled to a refraction index (RI) detector (Knauer Smartline 2300). The chromatographic separation was achieved with a Eurospher $100-5 \mathrm{NH}_{2}$ column $\left(5 \mu \mathrm{m}, 4.6 \times 250 \mathrm{~mm}\right.$, Knauer) operating at $30^{\circ} \mathrm{C}$ (7971 R Grace oven). The mobile phase was acetonitrile/deionized water, $70: 30(v / v)$ at a flow rate of $1 \mathrm{~mL} / \mathrm{min}$. The identification of the sugars was undertaken by comparing their peak relative retention times with commercial standards. Data were analysed through the Clarity 2.4 Software (DataApex, Podohradska, Czech Republic). Finally, the quantification was based on the RI signal response of each standard, relying on the internal standard (IS, raffinose) method and using calibration curves obtained from the commercial standards of each compound. The results were expressed in $\mathrm{g}$ per $100 \mathrm{~g}$ of dry weight.

\subsubsection{Fatty Acids}

Before the analysis of fatty acids, a trans-esterification procedure was performed, following a procedure previously reported [32]. The detection was also made by chromatographic techniques, in this specific case, by gas chromatography (GC). The GC equipment was composed by a gas chromatograph (DANI 1000, Contone, Switzerland), equipped with a split/splitless injector and a flame ionization detector (FID). Separation was achieved using a Macherey-Nagel (Düren, Germany) column (50\% cyanopropyl-methyl-50\% phenylmethylpolysiloxane, $30 \mathrm{~m} \times 0.32 \mathrm{~mm}$ i.d. $\times 0.25 \mu \mathrm{m}$ df). The oven temperature program was as follows: the initial temperature of the column was $50{ }^{\circ} \mathrm{C}$, held for $2 \mathrm{~min}$, then a $30^{\circ} \mathrm{C} / \mathrm{min}$ ramp to $125^{\circ} \mathrm{C}, 5{ }^{\circ} \mathrm{C} / \mathrm{min} \operatorname{ramp}$ to $160{ }^{\circ} \mathrm{C}, 20^{\circ} \mathrm{C} / \mathrm{min} \operatorname{ramp}$ to $180{ }^{\circ} \mathrm{C}, 3{ }^{\circ} \mathrm{C} / \mathrm{min}$ ramp to $200^{\circ} \mathrm{C}, 20^{\circ} \mathrm{C} / \mathrm{min}$ ramp to $220^{\circ} \mathrm{C}$ and held for $15 \mathrm{~min}$. The carrier gas (hydrogen) flow-rate was $4.0 \mathrm{~mL} / \mathrm{min}(0.61 \mathrm{bar})$, measured at $50^{\circ} \mathrm{C}$. Split injection (1:40) was carried out at $250{ }^{\circ} \mathrm{C}$. The identification was carried out by comparing the relative retention times of the fatty acid methyl esters (FAME) of the samples with commercial standards. The quantification was made 
using the Clarity 4.0.1.7 Software (DataApex), being the results expressed as relative percentages of each fatty acid.

\subsubsection{Tocopherols}

Vitamin E isoforms were also separated by HPLC (above mentioned and described), according to a procedure previously described by other authors [33]. The analysis was performed by coupling with a fluorescence detector (FP-2020; Jasco, Easton, MD, USA), which was programmed for excitation at $290 \mathrm{~nm}$ and emission at $330 \mathrm{~nm}$. The chromatographic separation was achieved with a Polyamide II $(5 \mu \mathrm{m}, 250 \times 4.6 \mathrm{~mm}$ ) normal-phase column from YMC Waters (YMC America, Inc., Allentown, PA, USA) operating at $30^{\circ} \mathrm{C}$. The mobile phase used was a mixture of n-hexane and ethyl acetate (70:30, $v / v$ ) at a flow rate of $1 \mathrm{~mL} / \mathrm{min}$. The peaks detected were compared with commercial standards, being the quantification based on the fluorescence signal, using the internal standard (tocol) method. The results were expressed in $\mu \mathrm{g}$ per $100 \mathrm{~g}$ of dry weight.

\subsection{Non-Nutrient Composition}

\subsubsection{Organic Acids}

Organic acids were detected by Ultra Fast Liquid Chromatography (UFLC). Detection was carried out coupling the chromatograph (Shimadzu 20A series, Shimadzu Corporation, Kyoto, Japan) to a photodiode array detector (PDA), using $215 \mathrm{~nm}$ and $245 \mathrm{~nm}$ as preferred wavelengths. Separation was achieved on a SphereClone (Phenomenex, Torrance, CA, USA) reverse phase C18 column $\left(5 \mu \mathrm{m}, 250 \mathrm{~mm} \times 4.6 \mathrm{~mm}\right.$ i.d.) thermostatted at $35{ }^{\circ} \mathrm{C}$. The elution was performed with sulphuric acid $(3.6 \mathrm{mM})$ using a flow rate of $0.8 \mathrm{~mL} / \mathrm{min}$. The organic acids found were quantified comparing the area of their peaks recorded at $215 \mathrm{~nm}$ with calibration curves obtained from commercial standards of each compound [34]. The results were expressed in $g$ per $100 \mathrm{~g}$ of dry weight.

\subsubsection{Phenolic Acids}

Phenolic acids analysis was performed using the Shimadzu 20A series ultra-fast liquid chromatograph (UFLC, Shimadzu Corporation, equipment described above) [35]. Separation was achieved using a Waters Spherisorb S3 ODS-2 $\mathrm{C}_{18}(3 \mu \mathrm{m}, 4.6 \mathrm{~mm} \times 150 \mathrm{~mm})$ column thermostatted at $35{ }^{\circ} \mathrm{C}$. The solvents used were: (A) $0.1 \%$ formic acid in water; (B) acetonitrile. The elution gradient established was $10 \%$ A to $15 \%$ B over $5 \mathrm{~min}, 15 \%-25 \%$ A in B over $5 \mathrm{~min}, 25 \%-35 \%$ $\mathrm{A}$ in $\mathrm{B}$ over $10 \mathrm{~min}$, isocratic $50 \% \mathrm{~B}$ for $10 \mathrm{~min}$, and re-equilibration of the column, using a flow rate of $0.5 \mathrm{~mL} / \mathrm{min}$. Double online detection was carried out in the PDA using $280 \mathrm{~nm}$ as preferred wavelength and in a mass spectrometer (MS) connected to HPLC system via the DAD cell outlet. The quantification of the phenolic compounds identified was made by comparison of the area of their peaks recorded at $280 \mathrm{~nm}$ with calibration curves obtained from the commercial phenolic standards: Gallic acid $\left(\mathrm{y}=224,587 \mathrm{x}-129,097 ; R^{2}=0.9997 ; \mathrm{LOD} 0.19 \mu \mathrm{g} / \mathrm{mL}\right.$; LOQ 0.63 $\mu \mathrm{g} / \mathrm{mL}) ;$ protocatechuic acid $\left(\mathrm{y}=116,749 \mathrm{x}-38733 ; R^{2}=1\right.$; LOD $0.29 \mu \mathrm{g} / \mathrm{mL}$; LOQ $\left.0.97 \mu \mathrm{g} / \mathrm{mL}\right)$; $p$-hydroxybenzoic acid $\left(\mathrm{y}=164,204 \mathrm{x}+12,917 ; R^{2}=0.9999 ; \mathrm{LOD} 0.11 \mu \mathrm{g} / \mathrm{mL} ; \mathrm{LOQ} 0.36 \mu \mathrm{g} / \mathrm{mL}\right)$; cinnamic acid (y = 863,668x - 884,517; $R^{2}=0.9998 ; \mathrm{LOD} 0.42 \mu \mathrm{g} / \mathrm{mL} ; \mathrm{LOQ} 1.41 \mu \mathrm{g} / \mathrm{mL}$ ). The results were expressed in mg per $100 \mathrm{~g}$ of dry weight.

\subsection{Antioxidant Properties}

\subsubsection{Extraction Procedure}

The lyophilized samples $(1 \mathrm{~g})$ were extracted by stirring with $40 \mathrm{~mL}$ of methanol at room temperature for $1 \mathrm{~h}$ and subsequently filtered through Whatman No. 4 paper. The residue was then extracted with an additional portion of methanol $(20 \mathrm{~mL})$ for $1 \mathrm{~h}$. The combined methanolic 
extracts were evaporated under reduced pressure at $40{ }^{\circ} \mathrm{C}$ (R-210 rotary evaporator, Büchi, Flawil, Switzerland) and re-dissolved in methanol $(20 \mathrm{mg} / \mathrm{mL})$ and stored at $4{ }^{\circ} \mathrm{C}$ for further use.

\subsubsection{Antioxidant Activity Evaluation}

From the stock solution, successive dilutions were made and submitted to the in vitro assays already described [35]. The sample concentrations $(\mathrm{mg} / \mathrm{mL}$ ) providing $50 \%$ of antioxidant activity or 0.5 of absorbance $\left(\mathrm{EC}_{50}\right)$ were calculated from the graphs of antioxidant activity percentages $(\mathrm{DPPH}$, $\beta$-carotene/linoleate and TBARS assays) or absorbance at $690 \mathrm{~nm}$ (ferricyanide/Prussian blue assay) against sample concentrations. Trolox was used as a positive control.

\section{- $\quad$ Reducing power}

The reducing power of the samples was measured through the Folin-Ciocalteu assay and the Ferricyanide/Prussian blue assays.

The Folin-Ciocalteu assay allows to quantify the total phenolics and other reducing species present in the samples, relying on their electron transfer capability. The absorbance was measured at $765 \mathrm{~nm}$ (Analytikijena 200-2004 spectrophotometer, Jena, Germany) and gallic acid was used to obtain the standard curve. The results were expressed as mg of gallic acid equivalents (GAE) per $g$ of extract.

Regarding the Ferricyanide/Prussian blue assay, the methodology of which is based on the capacity to convert $\mathrm{Fe}^{3+}$ into $\mathrm{Fe}^{2+}$, the absorbance was measured at $690 \mathrm{~nm}$ in a ELX800 Microplate Reader (Bio-Tek Instruments, Inc; Winooski, VT, USA).

- Radical scavenging activity

In the performed assay, the purple chromogen 2,2-diphenyl-1-picrylhydrazyl (DPPH) radical is reduced by antioxidant compounds to the corresponding pale yellow hydrazine. This methodology was accomplished using the microplate reader mentioned above, and the absorption measured at 515 $\mathrm{nm}$. The radical scavenging activity (RSA) was calculated as a percentage of DPPH discoloration using the equation: \%RSA $=[(\mathrm{ADPPH}-\mathrm{AS}) / \mathrm{ADPPH}] \times 100$, where AS is the absorbance of the solution containing the sample, and ADPPH, the absorbance of the DPPH solution.

- Lipid peroxidation inhibition

The lipid peroxidation inhibition was evaluated through the inhibition of $\beta$-carotene bleaching (or $\beta$-carotene/linoleate assay) and the TBARS assay.

In the $\beta$-carotene/linoleate assay, the presence of antioxidants in the samples and their capacity to neutralize the linoleate free radicals, avoids $\beta$-carotene bleaching, which can be evaluated measuring the absorbance at $470 \mathrm{~nm}$. Therefore, $\beta$-carotene bleaching inhibition was calculated using the following formula:

(Absorbance after $2 \mathrm{~h}$ of assay/initial absorbance) $\times 100$.

The thiobarbituric acid reactive substances (TBARS) assay is based on the decreasing of TBARS caused by the lipid peroxidation inhibition in porcine (Sus scrofa) brain homogenates due to the presence of antioxidants. This decrease can be measured spectrophotometrically at $532 \mathrm{~nm}$. The inhibition ratio (\%) was calculated using the following formula:

$$
\text { Inhibition ratio }(\%)=[(\mathrm{A}-\mathrm{B}) / \mathrm{A}] \times 100 \% \text {, }
$$

where A and B were the absorbance of the control and sample solution, respectively.

\subsection{Statistical Analysis}

For each species, three randomly chosen samples were used and all assays were carried out in triplicate. Results were expressed as mean values and standard deviation (SD). The results of each 
parameter were compared by means of a Student's $t$ test to determine the significant difference among samples, with $\alpha=0.05$. This analysis was carried out using JMP Statistical Discovery V. 10 program (IBM SPSS software, Armonk, NY, USA).

\section{Conclusions}

This work is the first to report the nutritional, chemical and bioactive properties of Leccinum molle (Bon) Bon and Leccinum vulpinum Watling. Given the chemical composition of both species, we conclude that they are a good food option for inclusion in today's diet, being a source of essential nutrients, as well as nutraceuticals and other biologically active compounds. They revealed a good nutritional value (low in fat) and proved to be rich in MUFA and PUFA, soluble sugars (other than sucrose or glucose) and vitamin E. Additionally, they also exhibited antioxidant properties, which corroborates the statement of these mushrooms as health foods.

Acknowledgments: IPATIMUP integrates the i3S Research Unit, which is partially supported by FCT, the Portuguese Foundation for Science and Technology. The authors are grateful to the Foundation for Science and Technology (FCT, Portugal) for the grant of F.S. Reis (SFRH/BD/111753/2015) and L. Barros (SFRH/BPD/107855/2015), and COMPETE/QREN/EU for the financial support to CIMO (strategic project PEst-OE/AGR/UI0690/2014).

Author Contributions: F.S. Reis, I.C.F.R. Ferreira, P. Morales and M.H. Vasconcelos conceived the study. F.S. Reis, P. Morales and I.C.F.R. Ferreira designed the experiments. F.S. Reis and A. Martins performed the taxonomic identification of the species, and the F.S. Reis carried out the assays. F.S. Reis and L. Barros performed data organization and analysis of the results. F.S. Reis, L. Barros and I.C.F.R. Ferreira wrote the manuscript. A. Martins, P. Morales and M. H. Vasconcelos revised the manuscript.

Conflicts of Interest: The authors declare no conflict of interest.

\section{References}

1. Kibby, G. A user-friendly key to the genus Leccinum in Great Britain. Field Mycol. 2000, 1, 20-29. [CrossRef]

2. Iwański, M.; Rudawska, M. Ectomycorrhizal colonization of naturally regenerating Pinus sylvestris L. seedlings growing in different micro-habitats in boreal forest. Mycorrhiza 2007, 17, 461-467. [CrossRef] [PubMed]

3. Saxén, R.; Ilus, E. Transfer and behaviour of 137Cs in two Finnish lakes and their catchments. Sci. Total Environ. 2008, 394, 349-360. [CrossRef] [PubMed]

4. Vaaramaa, K.; Solatie, D.; Aro, L. Distribution of $210 \mathrm{~Pb}$ and $210 \mathrm{Po}$ concentrations in wild berries and mushrooms in boreal forest ecosystems. Sci. Total Environ. 2009, 408, 84-91. [CrossRef] [PubMed]

5. Chen, D.M.; Bastias, B.A.; Taylor, A.F.S.; Cairney, J.W.G. Identification of laccase-like genes in ectomycorrhizal basidiomycetes and transcriptional regulation by nitrogen in Piloderma byssinum. New Phytol. 2003, 157, 547-554. [CrossRef]

6. Chen, D.M.; Taylor, A.F.S.; Burke, R.M.; Cairney, J.W.G. Identification of genes for lignin peroxidases and manganese peroxidases in ectomycorrhizal fungi. New Phytol. 2001, 152, 151-158. [CrossRef]

7. Asgar, M.A.; Fazilah, A.; Huda, N.; Bhat, R.; Karim, A.A. Nonmeat protein alternatives as meat extenders and meat analogs. Compr. Rev. Food Sci. Food Saf. 2010, 9, 513-529. [CrossRef]

8. Guillamón, E.; García-Lafuente, A.; Lozano, M.; D’Arrigo, M.; Rostagno, M.A.; Villares, A.; Martínez, J.A. Edible mushrooms: Role in the prevention of cardiovascular diseases. Fitoterapia 2010, 81, 715-723. [CrossRef] [PubMed]

9. Grangeia, C.; Heleno, S.A.; Barros, L.; Martins, A.; Ferreira, I.C.F.R. Effects of trophism on nutritional and nutraceutical potential of wild edible mushrooms. Food Res. Int. 2011, 44, 1029-1035. [CrossRef]

10. Kalač, P. Chemical composition and nutritional value of European species of wild growing mushrooms: A review. Food Chem. 2009, 113, 9-16. [CrossRef]

11. Kalač, P. A review of chemical composition and nutritional value of wild-growing and cultivated mushrooms. J. Sci. Food Agric. 2013, 93, 209-218. [CrossRef] [PubMed]

12. Pereira, E.; Barros, L.; Martins, A.; Ferreira, I.C.F.R. Towards chemical and nutritional inventory of Portuguese wild edible mushrooms in different habitats. Food Chem. 2012, 130, 394-403. [CrossRef] 
13. Reis, F.S.; Barros, L.; Sousa, M.J.; Martins, A.; Ferreira, I.C.F.R. Analytical methods applied to the chemical characterization and antioxidant properties of three wild edible mushroom species from Northeastern Portugal. Food Anal. Methods 2014, 7, 645-652. [CrossRef]

14. Ferreira, I.C.F.R.; Barros, L.; Abreu, R.M.V. Antioxidants in wild mushrooms. Curr. Med. Chem. 2009, 16, 1543-1560. [CrossRef] [PubMed]

15. Ferreira, I.C.F.R.; Vaz, J.A.; Vasconcelos, M.H.; Martins, A. Compounds from wild mushrooms with antitumor potential. Anticancer Agents Med. Chem. 2010, 10, 424-436. [CrossRef] [PubMed]

16. Gillingham, L.G.; Harris-Janz, S.; Jones, P.J.H. Dietary monounsaturated fatty acids are protective against metabolic syndrome and cardiovascular disease risk factors. Lipids 2011, 46, 209-228. [CrossRef] [PubMed]

17. McEwen, B.J.; Morel-Kopp, M.-C.; Chen, W.; Tofler, G.H.; Ward, C.M. Effects of Omega-3 polyunsaturated fatty acids on platelet function in healthy subjects and subjects with cardiovascular disease. Semin. Thromb. Hemost. 2013, 39, 25-32. [CrossRef] [PubMed]

18. Carocho, M.; Ferreira, I.C.F.R. A review on antioxidants, prooxidants and related controversy: Natural and synthetic compounds, screening and analysis methodologies and future perspectives. Food Chem. Toxicol. 2013, 51, 15-25. [CrossRef] [PubMed]

19. Hanson, J.R. The Chemistry of Fungi; Royal Society of Chemistry: London, UK, 2008.

20. Sharma, P.; Jha, A.B.; Dubey, R.S.; Pessarakli, M. Reactive oxygen species, oxidative damage, and antioxidative defense mechanism in plants under stressful conditions. J. Bot. 2012, 2012. [CrossRef]

21. Hung, T.M.; Na, M.; Thuong, P.T.; Su, N.D.; Sok, D.; Song, K.S.; Seong, Y.H.; Bae, K. Antioxidant activity of caffeoyl quinic acid derivatives from the roots of Dipsacus asper Wall. J. Ethnopharmacol. 2006, 108, 188-192. [CrossRef] [PubMed]

22. Baati, T.; Horcajada, P.; Gref, R.; Couvreur, P.; Serre, C. Quantification of fumaric acid in liver, spleen and unrine by high-performance liquid chromatography coupled to photodiode-array detection. J. Pharm. Biomed. Anal. 2011, 56, 758-762. [CrossRef] [PubMed]

23. Lian, H.Z.; Mao, L.; Ye, X.L.; Miao, J. Simultaneous determination of oxalic, fumaric, maleic and succinic acids in tartaric and malic acids for pharmaceutical use by ion-supression reversed-phase high performance liquid chromatography. J. Pharm. Biomed. Anal. 1999, 19, 621-625. [CrossRef]

24. Ranilla, L.G.; Kwon, Y.I.; Apostolidis, E.; Shetty, K. Phenolic compounds, antioxidant activity and in vitro inhibitory potential against key enzymes relevant for hyperglycemia and hypertension of commonly used medicinal plants, herbs and spices in Latin America. Bioresour. Technol. 2010, 101, 4676-4689. [CrossRef] [PubMed]

25. Morton, L.W.; Caccetta, R.A.A.; Puddey, I.B.; Croft, K.D. Chemistry and biological effects of dietary phenolic compounds: Relevance to cardiovascular disease. Clin. Exp. Pharmacol. Physiol. 2000, 27, 152-159. [CrossRef] [PubMed]

26. Heleno, S.A.; Martins, A.; Queiroz, M.J.R.P.; Ferreira, I.C.F.R. Bioactivity of phenolic acids: Metabolites versus parent compounds: A review. Food Chem. 2015, 173, 501-513. [CrossRef] [PubMed]

27. Carocho, M.; Ferreira, I.C.F.R. The Role of Phenolic Compounds in the Fight against Cancer-A Review. Anticancer Agents Med. Chem. 2013, 13, 1236-1258. [CrossRef] [PubMed]

28. Iwashina, T. The Structure and distribution of the flavonoids in plants. J. Plant Res. 2000, 113, $287-299$. [CrossRef]

29. Blokhina, O.; Virolainen, E.; Fagerstedt, K.V. Antioxidants, oxidative damage and oxygen deprivation stress: A review. Ann Bot. 2003, 91, 179-194. [CrossRef] [PubMed]

30. Association of Official Analytical Chemists. Official Methods of Analysis of AOAC International, 19th ed.; AOAC International: Gaithersburg, MD, USA, 2012.

31. The European Parliament and the Council of the European Union. Regulation (EC) No. 1169/2011 of the European Parliament and of the Council of 25 October 2011 on the provision of food information to consumers. Off. J. Eur. Union 2011, 304, 18-63.

32. Reis, F.S.; Barros, L.; Martins, A.; Ferreira, I.C.F.R. Chemical composition and nutritional value of the most widely appreciated cultivated mushrooms: An inter-species comparative study. Food Chem. Toxicol. 2012, 50, 191-197. [CrossRef] [PubMed]

33. Heleno, S.A.; Barros, L.; Sousa, M.J.; Martins, A.; Ferreira, I.C.F.R. Tocopherols composition of Portuguese wild mushrooms with antioxidant capacity. Food Chem. 2010, 119, 1443-1450. [CrossRef] 
34. Barros, L.; Pereira, C.; Ferreira, I.C.F.R. Optimized analysis of organic acids in edible mushrooms from Portugal by ultra fast liquid chromatography and photodiode array detection. Food Anal. Methods 2013, 6, 309-316. [CrossRef]

35. Reis, F.S.; Martins, A.; Barros, L.; Ferreira, I.C.F.R. Antioxidant properties and phenolics profile of the most widely appreciated cultivated mushrooms: A comparative study between in vivo and in vitro samples. Food Chem. Toxicol. 2012, 50, 1201-1207. [CrossRef] [PubMed]

Sample Availability: Mushroom voucher specimens are available from the authors.

(C) 2016 by the authors; licensee MDPI, Basel, Switzerland. This article is an open access article distributed under the terms and conditions of the Creative Commons by Attribution (CC-BY) license (http:/ / creativecommons.org/licenses/by/4.0/). 